\title{
Diskursus Reformasi Arab Saudi: Kontestasi Kerajaan Saudi Dan Wahabi
}

\author{
Mahmud Hibatul Wafi \\ Pasca Sarjana UIN Sunan Kalijaga Yogyakarta \\ Konsentrasi Kajian Timur Tengah \\ Email:mahmudwf@gmail.com
}

\begin{abstract}
Abstrak
Pengakuan publik yang dilontarkan pihak Saudi akan betapa kaku dan konservatifnya cara beragama negara tersebut mendatangkan perhatian dan pertanyaan besar bagi dunia Internasional. Reformasi sosial dan ekonomi adalah di atara rancangan yang dilancarkan Saudi. Pihak Saudi sendiri berniat untuk bertransformasi ke arah Islam moderat sebagai upaya untuk mereduksi bentuk-bentuk "kekakuan" dan sikap ekstremisme. Penelitian ini akan lebih mengarah kepada beberapa rumusan masalah yaitu, apa sebenarnya yang melatarbelakangi kebijakan reformasi pihak kerajaan Saudi dan bagaimana konstelasi pemerintahan Saudi ke depannya jika reformasi besar-besaran akan terjadi serta seperti apa pula reaksi asertif dan resistensi dari kubu Wahabi terhadap kebijakan tersebut. Selanjutnya, kehadiran paper ini akan coba menguraikan dan membentangkan asumsiasumsi diskursif melalui pendekatan decision making process untuk memahami lebih jauh maksud dari cita-cita reformasi Arab Saudi.
\end{abstract}

Kata Kunci : Arab Saudi, Reformasi,

\section{Wahabi Abstract}

A public recognition announced by Saudi about how strict and conservative the way they practice the religion, has been attracting attention and a big question worldwide. Social and economic reformation are the main plan that will be committed by Saudi. Saudi intend to transform to a moderate Islam, as an effort to reduce their rigidity and extremism. This research will lead to some of the problem statements which explain the background of the reformation policy carried out by the Kingdom of Saudi Arabia, and how the constellation 
of Saudi's government will be in the future if a massive reformation occur, as well as the assumptions of Wahhabi's assertive and resistance reaction towards the policy. This paper will try to elaborate and unveil discursive assumptions by DMP (decision making process) approach to further understand the intention of Saudi Arabia's reformation ideal.

Keywords: Saudi Arabia, Reformation, Wahabi

\section{Pendahuluan}

Sebagaimana diketahui secara jamak, Arab Saudi merupakan negara Islam yang dibangun berlandaskan AlQur'an dan Sunnah sebagai asas konstitusi negaranya. Konstitusi yang berlandaskan inti ajaran Islam tersebut memiliki konsekuensi berupa keterlibatan ulama' Wahabi di dalam peme- rintahan Arab Saudi.Selain itu, latar belakang historis Arab Saudi yang tidak bisa dipisahkan dari peran kelompok Wahabi baik dalam pendirian negara maupun pemerintahannya- (Izaqi, 2016: 388).

Bahwa antara Wahabisme dan Arab Saudi telah terjalin hubungan yang saling membutuhkan, saling menopang, dan bahkan hubungan mereka ini sangat menentukan mobilitas negara Saudi.Sejak pemerintahan King Abdul Aziz hingga sekarang, kaum Wahabi melayani negara atau selaku stakeholder, dan begitu juga dengan negara melayani kaum Wahabi, jadi di antara mereka ada
mutualism-relation.Di antaranya kaum Wahabi berperan aktif dalam memformulasikan model kebijakan hukum yang kemudian diimplimentasikan para pejabat negara. Melalui Wahabi, negara mengokohkan otoritasnya. Sejauh ini, hubungan antara Arab Saudi dan Wahabi berlangsung dengan sangat baik, lebih dari sekadar hubungan pragmatis dan saling memberi dukungan.Mereka juga saling bahu membahu menjawab persoalan tentang bagaimana model negara Islam, sikap negara terhadap modernisasi, dan sebagainya.

Melihat betapa eratnya hubungan Saudi dan Wahabi ini, sepertinya akan menjadi batu penghadang bagi misi reformasi ekonomi terutama sektor pariwisata- yang digagaskan oleh Muhammad bin Salman. Langkah ini diambil selain untuk menegaskan agenda modernisasi Arab Saudi 2030, juga paling pokok adalah untuk mewaspadai anjloknya perekonomian Saudi yang selama 
ini hanya bersandar pada minyak dan gas sebagai main commodity.

Posisi Wahabi dianggap akan mengusik penerapan kebijakan reformasi tersebut. Tidak bisa tidak arus modernisasi akan mempengaruhi kultur keagamaan yang selama ini dibangun oleh Wahabi. Apalagi pencanangan sektor pariwisata dipastikan akan bertentangan dengan corak keagamaan mereka.

Apabila merujuk ke teori fungsionalisme struktural bahwa masyarakat sebagai satu sistem yang terdiri dari bagian-bagian yang saling berhubungan satu sama lain dan bagian yang satu tak dapat berfungsi tanpa ada hubungan dengan bagian yang lain. Kemudian, perubahan yang terjadi pada salah satu bagian akan menyebabkan ketidakseimbangan dan pada gilirannya akan men- ciptakan perubahan pada bagian lain (Bourricaud, 1981: 94) . Maka demikian pulalah yang akan terjadi pada hubungan Saudi dan Wahabi, tidak bisa tidak akan memberi dampak bagi regulasi dan aristokrasi Saudi. Oleh karena itu, membaca seperti apa proyek reformasi Saudi dan pengaruhnya terhadap posisi Wahabi yang sangat dominan di Saudi serta sejauh mana kemungkinan bangkitnya spirit demokrasi yang pada akhirnya akan membahayakan sistem monarki Saudi akan menjadi titik fokus dalam pembahasan ini.

Kemudian, dalam merumuskan anasir yang turut serta dalam perumusan kebijakan Muhammad bin Salman, penulis juga menyertakan pendekatan Decision Making Process. Instrumen ini digunakan untuk menyuguhkan fokus kajian dalam membaca pengaruh kelompok dalam politik luar negeri. Di dalam sebuah proses pengambilan kebijakan, seorang pemimpin tidak berdiri sendiri. Ada sekelompok orang yang memiliki peran dan pengaruh dalam perumusan kebijakan luar negeri suatu negara (Lovel, 1970: 59).

\section{Cita-Cita Reformasi Saudi}

Ide reformasi yang digagas oleh Muhammad bin Salman (MBS) bisa ditanggapi sebagai perwujudan kekhawatiran kerajaan Saudi terhadap ladang perekonomian mereka. Minyak dan gas merupakan komoditi utama yang selama ini menopang negara tersebut tampak semakin tak bersahabat.Harga minyak semakin melemah dan persaingan ekonomi internasional semakin meningkat."Kecanduan" Saudi terhadap minyak bahkan bisa saja menjadi malapetaka 
bagi mereka bila tidak ada langkah yang brilian untuk mengantisipasinya. Data yang dirilis oleh Badan Moneter Internasional menyebutkan pertembuhan perekonomian Saudi anjlok menjadi $0,4 \%$. Ditambah lagi adanya peningkatan produksi minyak di AS yang mendorong acuan harga West Texas Intermediate (WTI) kembali ke bawah 50 dollar AS per barrel. Dan kondisi diprediksi akan terus berlanjut hingga akhir tahun 2018 ini (kompas, 8/17).

Kemudian tercetuslah rencana besar "Visi Ekonomi 2030" untuk mentransformasi perekonomian Saudi lebih baik dan menggiring Saudi ke arah yang lebih modern, moderat, dan terbuka pada dunia. Pengembangan dan diversifikasi sektor non-minyak menjadi target utama Saudi. Salah satunya pengembangan dan pembangunan sektor pariwisata. Bahkan MBS juga telah mengumumkan Saudi akan membangun sebuah lokasi wisata kelas dunia di kawasan Laut Merah lengkap dengan berbagai fasilitas modern, canggih, dan kaum hawa di pantai dibolehkan memakai bikini (middleeasteye.net, 28/10).

Visi Saudi 2030 tersebut juga menghendaki perombakan sektor sosial dan budaya sebagai bagian kesatuan negara.Saudi pun menunjukkan keterbukaannya dengan mengizinkan perempuan untuk mengemudi dan memasuki stadiun.Singkatnya, reformasi ekonomi mewajibkan adanya reformasi sosial.Di antara terobosan reformasi sosial -selain ruang publik bagi perempuan- yang diinisiasi oleh pihak kerajaan adalah pemberian lisensi bagi industri bioskop untuk beroperasi yang direalisasi pada Mei 2018 ini. Berkenaan dengan ini, Menteri Kebudayaan dan Informasi, Dr. Awwad Alawwad mengatakan, "Langkah ini hadir sebagai bagian dari agenda reformasi sosial dan ekonomi dalam bingkai "Visi 2030" di bawah kepemimpinan Putra Mahkota Muhammad bin Salman. Keputusan untuk mengizinkan bioskop adalah inti program pemerintah untuk mendorong dan mengapresiasi budaya lokal yang terbuka serta memperkaya kebudayaan masyarakat Saudi" (RiyadhConnect.com, 12/12).

Satu hal yang pasti, apapun agenda yang digaungkan MBS adalah upaya untuk mereduksi pelabelan konservatif dan fundamentalis oleh dunia internasional selama ini, dan kemudian direvisi dengan menampilkan Saudi yang inklusif. Namun, Saudi harus menyadari betapa asas konservatif yang dipupuk oleh klan Wahabi di 
negaranya telah mengakar cukup lama. Dan ini bukanlah kerja yang mudah.

\section{Sekilas tentang Wahabi}

Wahabi, sebuah platform Islam yang mempopulerkan gagasan purifikasi terhadap ajaran-ajaran Islam. Dicetus oleh Muhammad bin Abd al-Wahab sekitar abad 18 dan Saudi adalah sentral pergerakannya. Penyebaran Wahabi sendiri bisa terbilang sangat pesat, dimaklumi karena ada dukungan kerajaan Saud yang menopangnya. Adalah Muhammad ibn Saud, tokoh Bani Saud saat itu yang menjalin kontrak kerjasama dengan Muhammad bin Abd al-Wahab untuk meyebarluaskan paham tersebut (El-Fadl, 2005: 7). Dengan ditetapkannya Arab Saudi sebagai negara yang sah pada tahun 1932, paham Wahabi pun turut serta dideklarasikan sebagai ideologi negara Arab Saudi.

Cita-cita pemurnian Islam yang didengungkan oleh Wahabi ini sangat menentang keras terhadap segala bentuk 'amaliyyah yang berbau kurafat, sufistik, dan bid'ah.Cara berpikir mereka terhadap instrumen-instrumen agama pun sangat tekstualis dan konservatif.Demikian juga dengan semangat beragama mereka yang sangat mengedepankan ijtihad dan menganggap satu-satunya kebenaran bersumber dari ulama' mereka.

Bahkan pada masa awal ekspansinya, Wahabiyyin tak segansegan memerangi orang atau kabilah yang menolak ajaran mereka. Bila dakwah lisan tidak ditolerir, maka 'dakwah pedang' akan ambil alih. Sehingga, tak sedikit orang-orang yang terpaksa mengikuti ajaran mereka, atau paling tidak melarikan diri ke daerah lain (Ali, 1995: 54).

Sikap otoriter yang ditunjukkan Wahabi tersebut sungguh sangat bertentangan dengan nilai-nilai tauhid yang diwariskan oleh Rasulullah Saw.Tak dapat dimungkiri adanya kontradiksi antara goal - purifikasi Islam- dan implimentasi dakwah yang mereka lakukan.Bahkan Madawi Rasheed menyebutkan bawa karakter Wahabi adalah otoriter, konservatif, dan sangat pasif tehadap politik (Madawi Rasheed, 2007: 5).

Tak sedikit pula tokoh yang menilai bahwa semangat Islam yang dikampanyekan oleh Wahabi akan mengancam pluralitas dalam ajaran Islam. Dengan sinis, Azyumardi Azra menyatakan bahwa Wahabi adalah wajah Islam yang primitif atau dalam bahasa lain Bendle menyatakannya sebagai sebuah 
upaya imperalialisme agama dan Inggris (El-Fadl, 2005: 39).

(Bendle, 2007: 7).

Dengan hasil kerja sama ini,

Di antara beberapa prinsip Saud akhirnya mendapat otoritas atau ajaran Wahabi ialah (Nashir, 2006: 438), penuh dari Inggris untuk menakhodai kawasan Arab.

1. Mengembalikan ajaran Islam kepada al-Qur'an dan Sunnah (absolutisme Qur'an dan Sunnah)

2. Memurnikan pemikiran Islam dari tauhid yang menyesatkan dan berorientasi pada tauhid 'ubudiyyah

3. Menindak tegas segala bentuk amaliyyah bid'ah dan kurafat. Bagi kalangan Wahabi, semua yang tidak memiliki referensi dari Nabi adalah sesat sehingga berdampak pada ketidakmampuan kalangan Wahabi untuk melaksanakan ajaran agama secara dinamis.

4. Menghidupkan semangat jihad, dan lain-lain.

Kemunculan Wahabi pada mulanya telah dicurigai sarat dengan kejanggalan, diduga kuat Inggris adalah aktor di balik pergerakan mereka. Misinya tiada lain hendak menguatkan hegemoni dan otoritas mereka di kawasan Arab yang kaya akan minyak dan gas alam itu. Dinasti Utsmani sebagai musuh terberat akan dibuat tunduk dengan semangat koloni yang dijalin Saudi

Kemudian, Saudi bahu-membahu bersama Wahabi membangun negara atas kepentingan ideologis hingga hari ini.

\section{Reformasi, Wahabi, dan Demokrasi}

Dengan situasi ekonomi yang mengkhawatirkan, maka opsi reformasi di sektor sosial dan ekonomi pun digagas.Beberapa langkah reformasi yang dirumuskan di antaranya, membuka sektor pariwisata, pemerataan hukum lewat penindakan terhadap pe- laku korupsi, menekan potensi ekstremisme oleh para ulama', melonggarkan peraturan terhadap peran perempuan, dan lain-lain.

Di antara beberapa kebijakan yang telah diupayakan Saudi, terlihat jelas bahwa mereka sangat mengedepankan rational-approach. Dengan menekankan pada keputusan yang berkaitan dengan daya guna (Syamsi, 1971: 319-321). Juga terlihat kebijakan Saudi tersebut lebih bersifat objektif.Meski dasar-dasar pengambilan keputusannya terkesan sangat otoritatif bila ditinjau dari sisi Wahabi.Namun, 
wewenang yang dimiliki kerajaan membuat siapapun tak berkutik untuk melawannya.

Sejauh ini, belum terlihat keputusan- keputusan dibuat bersifat kognitif, karena secara eksplisit hasil final (output) reformasi Saudi ini masih belum jelas substansi dan haluannya. Menurut J. Reason, setiap pengambilan keputusan mesti menunjukkan artikulasi pemilihan satu jalur keputusan dari beberapa alternatif yang tersedia (Reason, 1990: ix). Hanya saja, Saudi berangkat dari keresahan terhadap sektor minyak sebagai latar belakang reformasi, sehingga membuka peluang reformasi bagi sektor lainnya, terutama sektor budaya dan agama.

Atas dasar economic interest Saudi tersebut, proses perancangan kebijakan terpolarisasi ke aspek ideological interest, dan Wahabisme adalah tumbalnya.Meski ini cukup riskan bagi Saudi, tapi penyelamatan kepentingan nasional secara global tampaknya lebih diutamakan. Dengan kata lain, kebutuhan atau ketergantungan Saudi terhadap eliteelite internasional dipandang masih cukup besar.

Ikhtiar reformasi yang sudah semestinya ditentukan oleh nilainilai ideal yang dicita-citakan oleh rakyat.Karena reformasi sendiri berangkat dari pemenuhan aspirasi rakyat.Apakah reformasi yang dilakukan Saudi ini selaras dengan kepentingan rakyat atau tidak?Ataukah hanya kepentingan kerajaan sepihak?

Sebagaimana yang telah disinggung di atas, reformasi Saudi ini akan dihadapkan dengan kultur masyarakat yang konservatif dan fundamentalis, terutama dalam beragama. Secara garis besar, kebijakan reformasi dinilai bertolak belakang dengan alam pikiran masyarakat Saudi.

Sedangkan reformasi memiliki makna, upaya untuk menata ulang hal-hal menyimpang yang sudah tidak sesuai dengan cita-cita rakyat. Dengan kata lain, reformasi menawarkan proses sistematis, terpadu, dan komprehensif yang berorientasi mewujudkan tata pemerintahan yang baik (good goverment) (Sedarmayanti, 2009:

67). Kemudian, Prasojo (2009) mengatakan bahwa reformasi merujuk pada upaya yang dikehendaki (intended changer), dalam suatu kerangka kerja yang jelas dan terarah. Oleh karena itu, persyaratan keberhasilan reformasi adalah eksistensi road map, menuju suatu kondisi, status, dan tujuan yang ditetapkan sejak awal (Prasojo, 2009: xv). 
Berangkat dari beberapa benturan yang melibatkan tiga pengertian di atas, secara eksplisit sejauh ini Saudi sudah menunjukkan langkah-langkah reformasi mereka, tinggal lagi indikator keberhasilannya masih perlu dipertanyakan dan ditinjau ulang. Cita-cita reformasi ini apakah sejalan dengan kultur dan aspirasi masyarakat Saudi sendiri, karena Saudi sebagai negara yang mendudukkan kebijakan pemerintah sebagai keputusan mutlak dan tak dapat ditolerir.

Karena kalau gagal, maka reformasi "kecil-kecilan" ala Saudi ini dimungkinkan akan lahirnya semangat demokrasi di kubu masyarakat. Dan itu bisa menjadi malapetaka bagi klan Saud. Hal ini juga menjadi "PR" besar bagi Saudi untuk mengawal jalannya proses reformasi tersebut.

Sejauh ini pada level masyarakat dan negara Saudi terbelah menjadi "Wahabi" dan "dinasti al- Saud". Bahkan juga ada kelompok ketiga yang tak kalah besar pengaruhnya, yaitu mereka yang menyambut gembira perselingkuhan antara Ikhwanul Muslimin dan Wahabi. Kelompok ketiga ini bisa jadi merupakan kubu oposisi yang terbesar di Saudi.

Alhasil, gesekan internal Saudi berpotensi berubah menjadi poros, dan tak jelas apakah MBS dapat mengendalikan benturan ini demi kepentingannya, ataukah negara ini akan terjebak pada episode yang lebih mendebarkan dan sarat gejolak, mengingat rekam jejak Saudi selama ini sebagai kerajaan yang tertutup dan represif.

Kendati ikhtiar reformasi terus dilakukan, bagi kelompok moderat, perubahan itu belum memuaskan. Mereka masih menuntut hak politik dan sipil serta pemilu demokratis.Terbukti, menjelang peringatan hari nasional, aparat keamanan menangkap puluhan aktivis dan ulama yang berencana melakukan unjuk rasa menuntut demokratisasi, menentang korupsi, dan pelanggaran HAM.Apakah MBS yang masih belia (32 tahun) mampu menyelesaikan masalahmasalah besar ini, terutama masalah demokratisasi?Nampaknya tidak, sesuai pernyataan Salman, "Demokrasi tidak boleh diterapkan di Saudi karena negeri ini terdiri dari suku-suku dan wilayahwilayah.Kalau demokrasi diterapkan, setiap suku dan wilayah akan memiliki partainya sendiri." Namun, gebrakan anti-korupsi masih akan terus dilakukan karena ini merupakan inti dari reformasi ekonomi dan kebijakan politik. 
Penahanan para pangeran dan pejabat bertujuan konsolidasi kekuasaan dan menarik dukungan internal dan internasional.Tapi MBS harus berhati-hati. Reformasi yang dijalankannya akan menciptakan banyak musuh dan persoalan baru (ismes.net: 17/11).

Selanjutnya, Karen Elliot House dalam On Saudi Arabia: its People, Past, Religion, Fault Lines, and Future menegaskan bahwa relasi antara Kerajaan Saud dengan ulama' Wahabi tidaklah stabil. Kerajaan kerap menghendaki modernisasi dan reformasi, tapi selalu muncul perlawanan dari ulama' Wahabi (Karen, 2012).Ini menandakan bahwa Wahabi sangat interaktif dan dominatif dalam menentukan arah pemerintahan.

\section{Islam Moderat sebagai New Religious Movement}

Sejauh ini, ulama Wahabi hanya berdiam diri dan tidak bisa berbuat apa-apa, mengingat keputasan raja yang bersifat mutlak dan tak ada celah bagi mereka untuk memberontak.Dari pihak kerajaan sendiri sudah mulai meningkatkan pengawasan- terhadap ulama'-ulama' yang dicap mengkampanyekan semangat ekstrimisme. Bagi kerajaan, ekstrimisme inilah yang menjadi biang sulitnya menghadirkan Islam Moderat di negaranya.

Dalam membangun visi misi, kerajaan terkesan sangat memanfaatkan otoritas yang dimiliki ulama' untuk mensosialisasikan ke masyarakat Saudi. Menunjukkan bahwa ulama' pun harus tunduk dengan keputusan kerajaan dan mesti bekerja sama demi terwujudnya reformasi sosial tersebut. Kesepakatan ulama' dapat dilihat ketika terjadi penangkapan besar- besaran terhadap beberapa pengeran dan menteri yang diklaim terlibat dalam kasus korupsi.

Adapun ulama- ulama' yang memberanikan diri menyatakan ketidaksetujuannya maka tidak ada ampun dan pasti akan dicekal. Seperti yang terjadi pada September lalu, beberapa ulama' dan imam masjid telah dipecat dan ditahan karena terindikasi meyebarkan paham ekstrimisme (ArabNews. com).Syekh Awad al-Qarni, Syekh Salman al-Awda beserta saudara laki-lakinya adalah di antara ulama' yang ditahan dan dijebloskan ke penjara isolasi tanpa tuntutan yang jelas (cnn.indonesia.com).

Menyikapi posisi Wahabi yang sangat signifikan bagi kerajaan Saudi, gagasan Islam Moderat pun dihembuskan untuk mengambil alih otoritas keagamaan Saudi. 
Model Islam moderat seperti apa yang dicita-citakan Saudi, sampai saat ini belum jelas konstelasinya. Namun, bisa dipahami orientasinya adalah memenggal habis kekakuan dan ekstrimisme dalam beragama.

Bila diperhatikan dengan saksama, jatuhnya pilihan ter- hadap model "Islam Moderat" meyakinkan bahwa Saudi sedang mencoba menampilkan bangunan new religious movement.Clarke (2006) menyatakan bahwa religious movementmengalami perubahan yang signifikan akibat globalisasi, atau lebih tepatnya bagaimana agama bisa beradaptasi dengan globalisasi. Kemudian bertransformasi menjadi new religiousmovement (NRM)yang lebih modern dan lebih mampu merespon perubahan zaman akibat globalisasi (Izaqi, 2006).Globalisasi menantang paradigma keagamaan klasik dan konservatif untuk hijrah ke format yang lebih relevan dengan perkembangan zaman.

Tak heran bila Islam moderat menjadi alternatif bagi Kerajaan Saudi untuk menggeser posisi Wahabi. Namun, apakah ada jaminan Islam moderat yang diinginkan MBS tersebut akan memberi warna baru bagi masyarakat Saudi? Di sini komitmen dan integritas MBS dipertaruhkan.

\section{Kesimpulan}

Tidak bisa dimungkiri bahwa Wahabi sangat dominatif dalam menentukan kebijakan dan regulasi Kerajaan Saudi selama ini.Wahabi dengan semangat konservatif dan fundamentalisnya pulalah yang mengkonstruksi sektor sosial, budaya, dan keagamaan Saudi.

Tercetusnya kebijakan reformasi ekonomi dan sosial oleh Muhammad bin Salman tidak bisa tidak akan berimplikasi pada posisi Wahabi. Bertransformasi ke arah yang lebih moderat salah satu alternatifnya.Ulama' Wahabi sejauh ini masih berdiam diri dan ada juga yang mensupport kebijakan reformasi kerajaan, terutama soal penegakan hukum memberantas korupsi.

Di lain hal, cita-cita reformasi ini tidak bisa tidak akan melibatkan partisipasi dominan dari masyarakat Saudi sendiri. Adanya hal ini tentu akan membahayakan konstruksi monarki Saudi. Dibuktikan dengan tuntutan dari beberapa kalangan yang mempertanyakan hak politik dan sipil serta meminta adanya pemilu demokratis. Kemudian, tidak menutup kemungkinan arah pemerintahan Saudi akan bergeser ke demokrasi. Selama ini pun, dicermati bahwa Wahabilah yang berperan sebagai garda terdepan 
menghalangi masuknya semangat demokrasi di negara Ka'bah tersebut.

Oleh karena itu, komitmen pihak kerajaan Saudi sangat dibutuhkan untuk menjamin proyek reformasi tersebut agar berjalan baik dan kondusif.Salah satunya, mampu mereduksi adanya pengaruh atau intervensi yang berlebihan pihak luar (Barat). Karena bagaimanapun, momentum reformasi ini akan menjadi ajang bagi Barat untuk menguatkan hegemoni mereka di Arab Saudi.

\section{Daftar Pustaka}

Abou El-Fadl, Khaled. 2005. The Great Theft: Wresting Islam from the Extremists, San Fransisco: Harper Publisher.

Ali, Mukti. 1995. Alam Pikiran Islam Modern di Timur

Tengah, Jakarta: Djambatan.

Bendle, Mervyn F.2007. "Secret Saudi Funding of Radical Islamic Groups In Australia". National Observer (Council for the National Interest, Melbourne), No. 72.

Bourricaud, Francois.The Sociology

of Talcott Parsons, Chicago:

Chicago University Press.

Clarke, Peter B,2006.New Religious in Global Perspective: A Study of
Religions Change in The Modern

World, Routledge,New York.

Dougherty, James E. Pfaltzgraff,1971.

Contending Theories of

International Relations, New

York: Lippincot.

House, Karen Elliot.2012.On Saudi Its People, Past, Religion, Arabia Fault Lines and Future, Kanada:

Random House.

Izaqi, M. Syafrizal.2016. "Pengaruh

Kelompok Wahabi Terhadap

Politik Luar Negeri Arab Saudi

Dalam Arab Spring di Mesir Tahun 2011-2013," Jurnal

Analisis Hubungan Internasional, Vol. 5 No. 2, Juni.

Karim,Nashir bin Abdul. 2006.

Hanya Islam Bukan Wahabi, Jakarta: Darul Falah.

Lovel, John P. 1970. Foreign Policy in Perspective:

Strategy, Adaptation, Decision Making, New York: Holt, Rinehart and Winston, Inc.

Prasojo, Eko.2009.Reformasi Kedua:

Melanjutkan Edtafet Reformasi, Jakarta: Salemba Humanika.

Rasheed, Madawi.2007.Contesting the Saudi State: Islamic Voices from a New Generation, New York:

Cambridge University Press.

Reason, James.1990.Human Error.

Ashgate. 
Syamsi,Ibn. 2000. Pengambilan

Keputusan dan Sistem Informasi,

Jakarta: Bumi Aksara.

Sedarmayanti, 2009.Sumber Daya

Manusia dan Produktifitas

Kerja. Bandung: CV. Mandar

Maju. 